FULL RESEARCH ARTICLE

\title{
Thematic and hotspot analysis of human-elk conflicts statewide in California
}

\author{
KRISTIN DENRYTER ${ }^{1,3 *}$ AND ALEX HEEREN ${ }^{2}$
}

${ }^{1}$ California Department of Fish and Wildlife, Elk and Pronghorn Program, Wildlife Branch, 1010 Riverside Parkway, West Sacramento, CA 95606 USA (Former)

${ }^{2}$ California Department of Fish and Wildlife, Human Dimensions of Wildlife Unit, Wildlife Investigations Lab, 1701 Nimbus Road, Rancho Cordova, CA 95670 USA

${ }^{3}$ Alaska Department of Fish and Game, Wildlife Nutrition Lab 1800 Glenn Hwy \#2, Palmer, AK 99645 (Present)

*Corresponding Author: Kristin.Denryter@alaska.gov

Human-wildlife conflicts are an important factor for consideration in wildlife management at urban-wildland interfaces. Effective and adaptive management of human-wildlife conflicts is needed to promote tolerance and coexistence of humans and wildlife. Anecdotal reports suggest a recent spike in human-elk conflicts in California, yet there has not been a systematic analysis of human-elk conflicts in the state. To better understand human-elk conflicts in California, we conducted thematic analysis of human-elk conflicts reported in the California Department of Fish and Wildlife's Wildlife Incident Reporting (WIR) system. We also conducted a hotspot analysis using locations of human-elk conflicts reported in the WIR system and evaluated reports for principles of adaptive management. The WIR system contained $n=89$ reports for elk and $n=78$ of these described conflicts with elk. Overall, property damage (including crop damage) was the most common type of human-elk conflict reported, occurring in $69 \%$ of reports $(n=54 / 78)$, followed by non-competitive conflict with domestic animals (13\%), competition with domestic livestock $(12 \%)$, and habituation to humans $(24 \%)$. We identified three hotspots of human-elk conflict in California in Del Norte, Kern, and San Luis Obispo counties. All incidents of human-elk conflict reported in the WIR system included at least one principle of adaptive management. We recommend modifications to the WIR system and interactions with property owners and stakeholders to enhance and facilitate adaptive management of human-elk conflicts in California.

Key words: adaptive management, Cervus canadensis, conflict transformation, crop damage, depredation, fence damage, forage competition, property damage 
Conflicts between humans and wildlife are an important aspect of wildlife conservation and management, particularly in areas where expansive urban-wildland interfaces exist. Human-wildlife conflicts at urban-wildland interfaces can range from mild nuisance (e.g., deer eating a flower or vegetable garden; Drake et al. 2005) to monetary losses from crop or domestic animal depredation (Madhusudan 2003; Mackenzie and Ahabyona 2012) and destructive property damage (e.g., bears breaking into vehicles and buildings; Madison 2008). Human-wildlife conflicts can undermine species conservation efforts (Inskip and Zimmermann 2009; Mateo-Tomás et al. 2012) and can impact public support for conservation and management policies (Redpath et al. 2004; Madden and McQuinn 2014). Therefore, conflict transformation (Madden and McQuinn 2014) is critical in managing and conserving wildlife at the urban-wildland interface.

Previous studies of human-wildlife conflict often have focused on social tolerance of large carnivores (e.g., Treves et al. 2004; Madison 2008; Bruskotter et al. 2009; Slagle et al. 2013; Bruskotter and Wilson 2014; Bautista et al. 2017). Large herbivores, such as deer (Odocoileus spp.) and elk (Cervus canadensis), also can be a significant source of human-wildlife conflict (Van Tassell et al. 2000; Lee and Miller 2003; Walter et al. 2010). Herbivorous species can cause "depredation" (i.e., property damage or destruction, consistent with California Fish and Game Code section 4181) when they consume agricultural crops or cause damage to trees, shrubs, fences, or buildings (VerCauteren et al. 2006; Hegel et al. 2009; Walter et al. 2010). Large herbivores also can pose a risk to human health and safety through vehicle collisions (Gagnon et al. 2007) and as vectors of zoonotic disease (Michalak et al. 1998; Rhyan et al. 2013). In recent years, the need to better understand conflicts between humans and elk was identified as one objective in California's Elk Conservation and Management Plan, hereafter the California Elk Plan (California Department of Fish and Wildlife (CDFW) 2018). The California Elk Plan calls for alleviation of human-elk conflict and emphasizes growing elk populations by $10 \%$ where conflict is expected to be minimal (CDFW 2018). To know where conflict is expected to be minimal, first it is necessary to understand what constitutes human-elk conflict in California. While anecdotal reports suggest elk conflicts in California are largely related to depredation, including property damage, a more robust and systematic approach is needed to quantitatively assess conflict and meet goals identified in the California Elk Plan. Establishing a baseline of conflicts from data also is necessary to map "hotspots" of human-elk conflicts, which also was identified as a need in the California Elk Plan.

The California Elk Plan also emphasizes the importance of adaptive management, which is a structured, iterative process used to make, evaluate, and learn from management decisions with the overall goal of improving management and decreasing uncertainty over time (Stankey et al. 2005; Williams et al. 2009; Williams 2011). Although definitions and structures for adaptive management vary, they typically involve the following elements, structured in an iterative process: (1) conceptualizing the problem, (2) planning monitoring and other actions, (3) implementing planned actions, (4) analyzing and interpreting results, and (5) adapting strategies based on results. Understanding what human-elk conflict is occurring, and where it is occurring in the state, is central to conceptualizing the scope of the problem and is a necessary first step in the adaptive management process.

To support goals for elk conservation and management identified in the California Elk Plan (CDFW 2018), we systematically reviewed reports of human-elk conflict submitted to the California Department of Fish and Wildlife (CDFW). Our objectives were to: (1) describe 
predominant themes of human-elk conflict in California; (2) map hotspots of human-elk conflicts throughout California; (3) and evaluate whether responses to human-elk conflict were consistent with principles of adaptive management. We also identified other potential sources of human-elk conflict not reported in the WIR system, future research priorities, and provided recommendations to enhance management and resolution of human-elk conflicts in California.

\section{METHODS}

\section{Study Area}

California is home to three subspecies of elk-Rocky Mountain (Cervus canadensis nelsoni), Roosevelt (C.c. roosevelti), and tule (C. c. nannodes; endemic only to California) that are distributed throughout 22 Elk Management Units (EMUs; Fig. 1). Though once

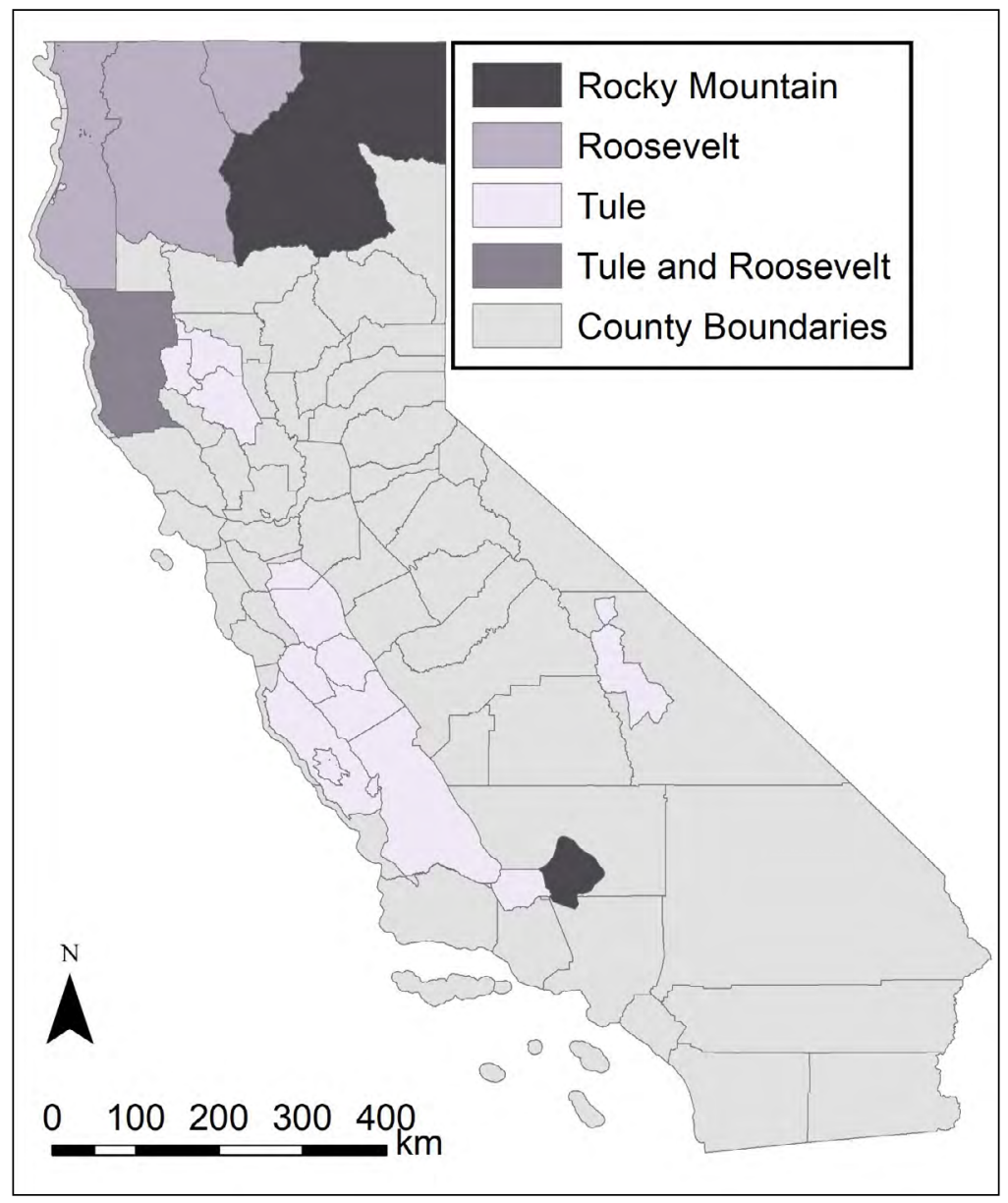

Figure 1. Distribution of Rocky Mountain, Roosevelt, and tule elk in 22 elk management units in California (current as of December 2020; locations of confined herds are not shown). 
decimated throughout California - and in some cases pushed to the brink of extinction (tule elk) or extirpation (Roosevelt elk) —all three subspecies of elk in California are increasing in number and distribution throughout the state (CDFW 2018).

Roosevelt elk in California occur primarily in the North Coast and Klamath Province, from coastal Mendocino County north to Humboldt and Del Norte counties, as well as part of Shasta, Trinity, Tehama, and Siskiyou counties. Roosevelt elk use various types of habitats including montane and bottomland grasslands, oak woodlands, coastal dunes, coastal coniferous rainforests, and wetlands. Predominant tree species are hemlock (Tsuga heterophylla), grand fir (Abies grandis), Douglas fir (Pseudotsuga menziesii), chinquapin (Chrysolepsis chrysophylla), noble fir (Abies procera), white fir (Abies concolor), and red fir (Abies magnifica). Coastal habitats are characterized by mild temperatures and substantial rainfall, whereas more interior areas experience rain-shadow effects and extreme temperatures. Elevation ranges from approximately 0-4200 m. Land ownership varies among each Elk Management Unit occupied by Roosevelt elk: $80 \%$ of land in the Mendocino Roosevelt Elk Management Unit is privately owned, compared to $40 \%$ and $35 \%$ of land in the North Coast and Marble Mountains EMUs being privately owned (CDFW 2018). Primary land uses on private lands include forestry, livestock operations (e.g., dairy farming, ranching), and commercial crop production (e.g., lilies, pumpkins).

Rocky Mountain elk occur primarily in northeastern California in the Cascades and Modoc Plateau province in Modoc, Siskiyou, Lassen, Plumas, Butte, and Shasta counties. Habitat types available to Rocky Mountain elk in northeastern California include blue oak (Quercus douglasii)-foothill pine (Pinus sabiniana), Sierran mixed conifer, montane hardwood-conifer, Ponderosa pine (Pinus ponderosa), and montane hardwood. Elevation ranges from 240-3,000 $\mathrm{m}$ (CDFW 2018). Predominant tree species include lodgepole pine (Pinus contorta), western white pine, ponderosa pine (Pinus monticola), white fir (Abies concolor), and aspen (Populus tremuloides: CDFW 2018). Land ownership is approximately $55 \%$ public and predominant land uses on private lands include forestry, livestock operations, and agricultural crop production. Another population of Rocky Mountain elk occurs in in Kern County, in central California - part of the Central Valley and Sierra Nevada Province (CDFW 2018). In the 1960s, a local ranch operator imported Rocky Mountain elk to the area from Yellowstone National Park; poor fence maintenance on the ranch resulted in elk escaping confinement and establishing a free-ranging population (CDFW 2018). Rocky Mountain elk in Kern County use habitats ranging in elevation from 900-2,400 m (CDFW 2018). Land ownership is primarily private within the EMU, and land is used for farming and livestock grazing (CDFW 2018). As of 2018, private property conflicts were considered minor (CDFW 2018). Additionally, there are Rocky Mountain elk on a private ranch on California's Central Coast, in San Luis Obispo County.

Tule elk have the broadest distribution of all three subspecies of elk in California, occurring in the North Coast and Klamath (Mendocino County), Bay Delta and Central Coast (Solano, Marin, Alameda, San Joaquin, Santa Clara, parts of Stanislaus, Monterey, and San Luis Obispo counties), Central Valley and Sierra Nevada (Lake, Colusa, Glenn, Yolo, parts of Stanislaus, Merced, and Kern counties), and Deserts provinces in California (Owens Valley, Inyo County). Predominant habitat types in the Bay Delta and Central Coast Province include estuarine marshes (e.g., at Grizzly Island Wildlife Area); annual grasslands; blue oak, interior live oak (Quercus wislizeni), and mixed oak-foothill pine woodlands; mixed chapparal, and riparian (CDFW 2018). Common wetland plants in estuarine marshes include 
saltgrass (Distichlis spicata), pickleweed (Salicornia virginica), tules (Scirpus spp.), cattails (Typha spp.), Baltic rush (Juncus balticus), and fat hen (Atriplex triangularis). Grassland plants include brome (Bromus spp.), wild oats (Avena spp.), fescues (Festuca spp.), ryes (Lolium spp.), tall wheatgrass (Elytrigia spp.), and mustards (Brassica spp.; CDFW 2018). Habitat types in the Central Valley and Sierra Nevada province includes annual and perennial grasslands, mixed chaparral, blue oak woodlands, blue oak-foothill pine, valley oak (Quercus lobata) woodlands, coastal chapparal (CDFW 2018). Elevation ranges from 0-2,700 m. Up to $90 \%$ of lands in some EMUs in the Central Valley and Sierra Nevada and Bay Delta and Central Coast provinces are privately owned and these areas are the most densely populated within the range of tule elk (CDFW 2018). Primary land uses include residential and commercial developments, agricultural crop production, and livestock grazing. The climate is Mediterranean and characterized by hot, dry summer, and cool, moist winters (CDFW 2018). Oak, pine, chamise (Adenostoma fasciculatum) and Ceanothus (Ceanothus spp.) comprise the predominant trees and shrubs (CDFW 2018). In the Desert province, habitat types are primarily Great Basin and Mojave Desert shrub communities, with predominant species of vegetation varying across elevational and moisture gradients, including saltbush (Atriplex spp.), sagebrush (Artemisia spp.), rabbitbrush (Chrysothamnus nauseosum), greasewood (Sarcobatus vermiculatus), saltgrass (Distichlis spicata), shadescale (Atriplex confertifolia), bitterbrush (Purshia spp.), mountain mahogany (Cercocarpus ledifolius) and Ceanothus (CDFW 2018). In riparian areas, willows (Salix spp.), cottonwood (Populus fremonti), and cattails (Typha domingensis) predominate and $>95 \%$ of land ownership is public, with the Los Angeles Department of Water and Power being the primary landowner in the Owens Valley (CDFW 2018). Additional information on geophysical and ecological descriptions of California's ecological provinces and habitat types available to elk is provided in the California State Wildlife Action Plan (CDFW 2015) and the California Elk Plan (CDFW 2018).

\section{Data Collection and Analyses}

To identify major categories of human-elk conflict and conflict hotspots in California, we queried CDFW's Wildlife Incident Reporting (WIR) system for all entries on elk. Since 2016, the California Department of Fish and Wildlife has used the WIR system to track and respond to human-wildlife conflicts; depredation permits and reports from years prior to 2016 are being migrated into the WIR system. Any member of the public can report incidents through the Department's public web page for the WIR system (https://apps.wildlife.ca.gov/ WIR/). The reporting party (RP) enters information about the incident, including species, date, type of incident (e.g., concern for animal welfare, depredation, general nuisance, mortality, potential human conflict, sighting, and public safety). Based on the location of the incident, the WIR system automatically assigns a CDFW investigator (either a biologist or a wildlife officer) who reviews the report and determines what action, if any, is appropriate. The investigator may conduct an investigation and provide advice on mitigation measures, or in some cases, may issue a depredation permit to the RP. While not all reports of conflict go through the WIR system (some calls go directly to CDFW staff in regional offices), it is the only centralized database of conflict incidents available to CDFW staff statewide.

After querying the WIR system for all reported elk incidents, we conducted a thematic analysis, using an inductive and semantic approach (Braun and Clarke 2006). That is, we allowed the data to determine themes and analyzed explicit content of WIR reports, rather than coming to the data with predetermined themes and reading into subtext and assump- 
tions motivating responses. We familiarized ourselves with the data and then identified and coded themes from the data, first at relatively coarse scales and then used secondary codes to describe subthemes within the data.

To map hotspots of human conflict, we overlaid locations of conflict (excluding reports categorized as 'sightings'). Incident data were aggregated by counting incidents within fishnet polygons using the Optimized Hot Spot Analysis tool in ArcMap 10.4 (Environmental Systems Research Institute, Redlands, CA). We conducted the analysis at the statewide level to ensure adequate sample sizes (i.e., a minimum of 30 points per polygon are required for hotspot analyses in ArcMap).

Finally, we evaluated whether departmental responses to conflict were consistent with the five principles of adaptive management (1) conceptualize (and defining) the problem, (2) plan monitoring and other actions, (3) implement planned actions, (4) analyze and interpret results, and (5) adapt strategies based on results. We evaluated language and content of reports for evidence of principles of adaptive management as follows. If incident reports described the incident type explicitly (e.g., RP categorized incident as depredation) or the incident type could be inferred from language used in the description (e.g., elk attacking livestock), reports were considered to meet principle 1. If incident reports or responses included a description of plans for monitoring, they were considered to meet principle 2 . Principles 3 and 4 were considered met if information was provided on how monitoring plans and actions were implemented, including any outcomes related to these plans and actions. We considered principle 5 met if responses were adapted based on results and outcomes associated with principle 3 and 4 .

\section{RESULTS}

The Wildlife Incident Reporting system contained $\mathrm{n}=89$ reports for elk reported between 3 Nov 2009 and 4 Oct 2020 (Fig. 2, 3). These included n=62 (70\%) reports categorized as depredation by elk, $\mathrm{n}=11(12 \%)$ reports categorized as general nuisance by elk, $\mathrm{n}$ $=7(8 \%)$ reports categorized as potential human conflicts with elk, and $n=9(10 \%)$ reports categorized as sightings of elk (Fig. 4). Incidents were reported in 12 counties (Figs. 3, 4). Reports characterized as sightings and those related to concerns over animal welfare were excluded from analyses as they did not constitute human-elk conflict. For reports describing human-elk conflict $(\mathrm{n}=78)$, we identified four predominant themes: (1) property damage (including crop damage), (2) injury or harm to domestic animals, (3) competition with domestic livestock, and (4) habituation to humans. Many reports $(n=27)$ described conflicts related to more than one of the predominant themes or multiple incidents per subtheme (e.g., multiple crops reported damaged).

Property damage was the most common type of conflict with elk reported in the WIR system, occurring in $69 \%(n=54)$ of reports a total of $n=85$ times. Fence damage was the most frequently reported subtheme of property damage $(n=32)$, followed by crop damage $(n=27)$, damage to landscape or landscaping $(n=9)$, damage to orchards $(n=9)$, and damage to vineyards $(n=5)$. Reports of crop damage included eating crops, trampling crops, and defecating in crops. Affected crops included lettuce, lilies, alfalfa, corn, cauliflower, broccoli, green onion, and green chard, however, not all reports specified a type of crop damaged. Fruit (e.g., apple, plum) and nut (e.g., almond) trees were damaged by elk rubbing antlers and stripping bark from trees. Landscape damage included damage to lilacs (n $=1$ ), tropical flowers $(\mathrm{n}=1)$, gardens (including vegetables; $\mathrm{n}=3$ ), and other non-specific 


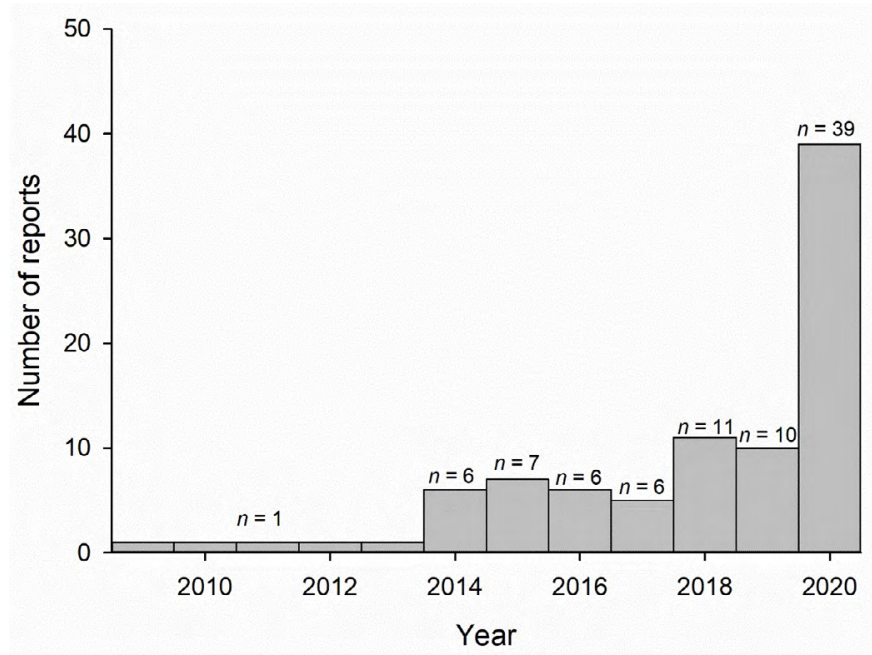

Figure 2. Number of reports concerning elk, by year, in the Wildlife Incident Reporting (WIR) system in California from 4 Nov 2009-4 Oct 2020.

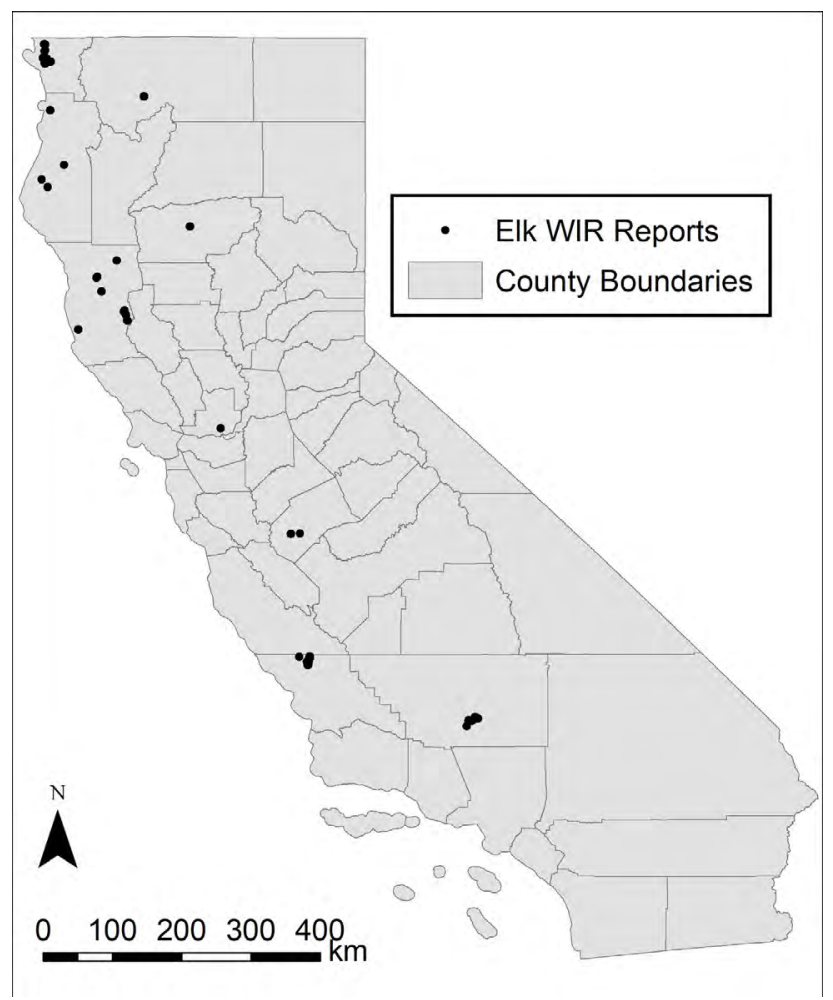

Figure 3. Locations of all Wildlife Incident Reporting (WIR) system reports concerning elk throughout California from 4 Nov 2009-4 Oct 2020. 


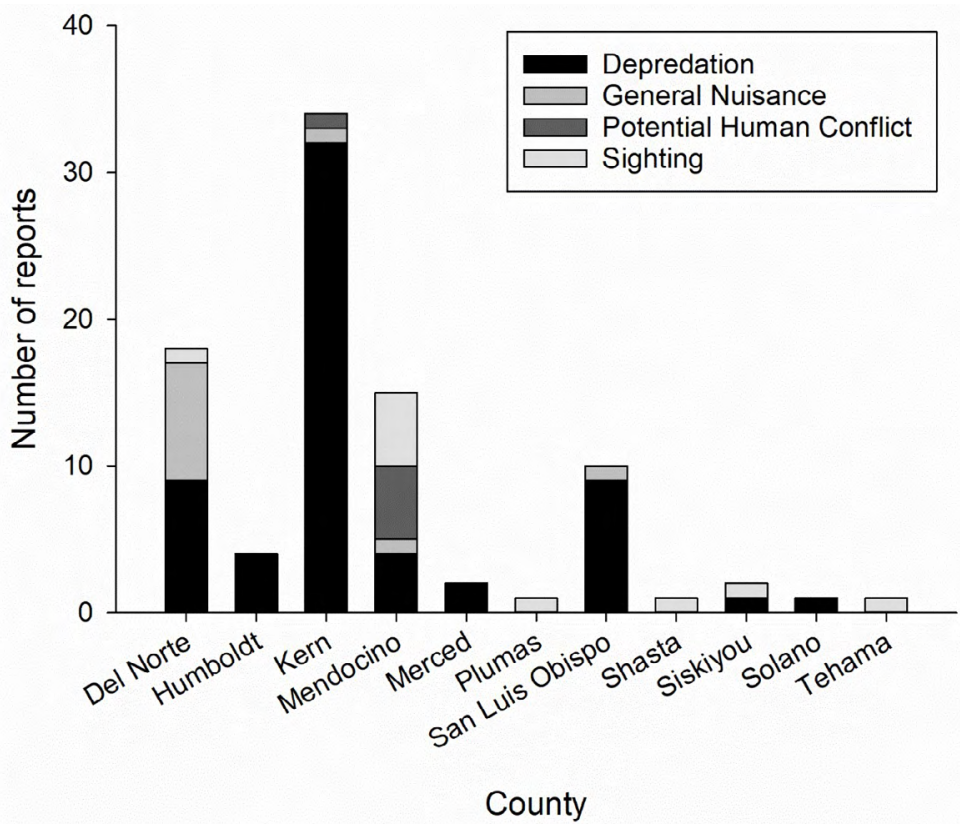

Figure 4. Number of Wildlife Incident Reporting (WIR) system reports concerning elk, by report category, from 4 Nov 2009-4 Oct 2020.

damage (e.g., damage to "field", "shrubs", "bushes"). Other reports of property damage mentioned damage to tractors, game cameras, antennas, and metal trash cans. Incidents of conflicts between elk and domestic animals were described in $n=19$ reports, including incidents described as competition with domestic livestock ( $\mathrm{n}=9 ; 12 \%$ of all conflict reports) and non-competitive conflicts with domestic animals $(\mathrm{n}=10 ; 13 \%$ of all conflict reports). Competition with domestic livestock included $n=8$ reports of elk consuming pasture or forages (e.g., grass, hay) and animal feed and one report suggested elk were competing with livestock for water. Non-competitive conflicts included $n=7$ reports of elk harassing or injuring domestic animals. Male elk were reported to stomp cattle calves and injure or break calves' legs $(n=2)$. One report described an elk attacking and severely injuring a dachshund (small breed dog). Another report described a dog barking at elk and then being kicked by a female elk. Three other reports included reports of elk chasing pets, harassing horses, or safety concerns of elk endangering children. Livestock also were reported missing after elk damaged fences $(n=3)$.

Habituation (e.g., a lack of wariness or fear, failure to disperse) to humans was described in $24 \%$ of all conflict reports. In most (17 out of 19 reports), habituation was reported with concerns about depredation, not as a stand-alone incident. The two stand-alone reports of habituation described an elk approaching or not moving away from a highly trafficked hiking trail and a concern that an elk was nearby (however, no aggression was described). Efforts to haze elk were described in $n=17$ reports of property damage, with habituation to humans (including hazing activities) described in $n=16$ reports. Elk were described as 
unafraid of people, vehicles, loud noises (e.g., gunshots, noisemakers), lights, being hit with rubber bullets, or if they were deterred, they sometimes returned within minutes to hours after deterrence was suspended.

We identified three hotspots of human-elk conflict in California using $n=78$ locations of human-elk conflict reported throughout California in hotspot analysis at the $99 \%$ confidence level. Human-elk conflict hotspots occurred in Del Norte, Kern, and San Luis Obispo counties, with the latter conflict hotspot extending into Monterey County (Fig. 5). All areas outside of the three identified conflict areas were determined to be non-significant in the hotspot analysis.

Among WIR system reports, $\mathrm{n}=89$ conceptualized the problem (principle 1 of adaptive management). Actions by CDFW were reported for $\mathrm{n}=72$ incidents, but few included substantive detail regarding specific responses; systematic monitoring (principle 2) was not planned as part of any responses. The most common action by CDFW was to advise (or attempt to advise - outreach with no response) the RP $(n=65)$ on actions that could be implemented, but only $\mathrm{n}=1$ incident mentioned continued communication (i.e., monitoring) between the RP and CDFW regarding the conflict. Except for reports of elk taken under

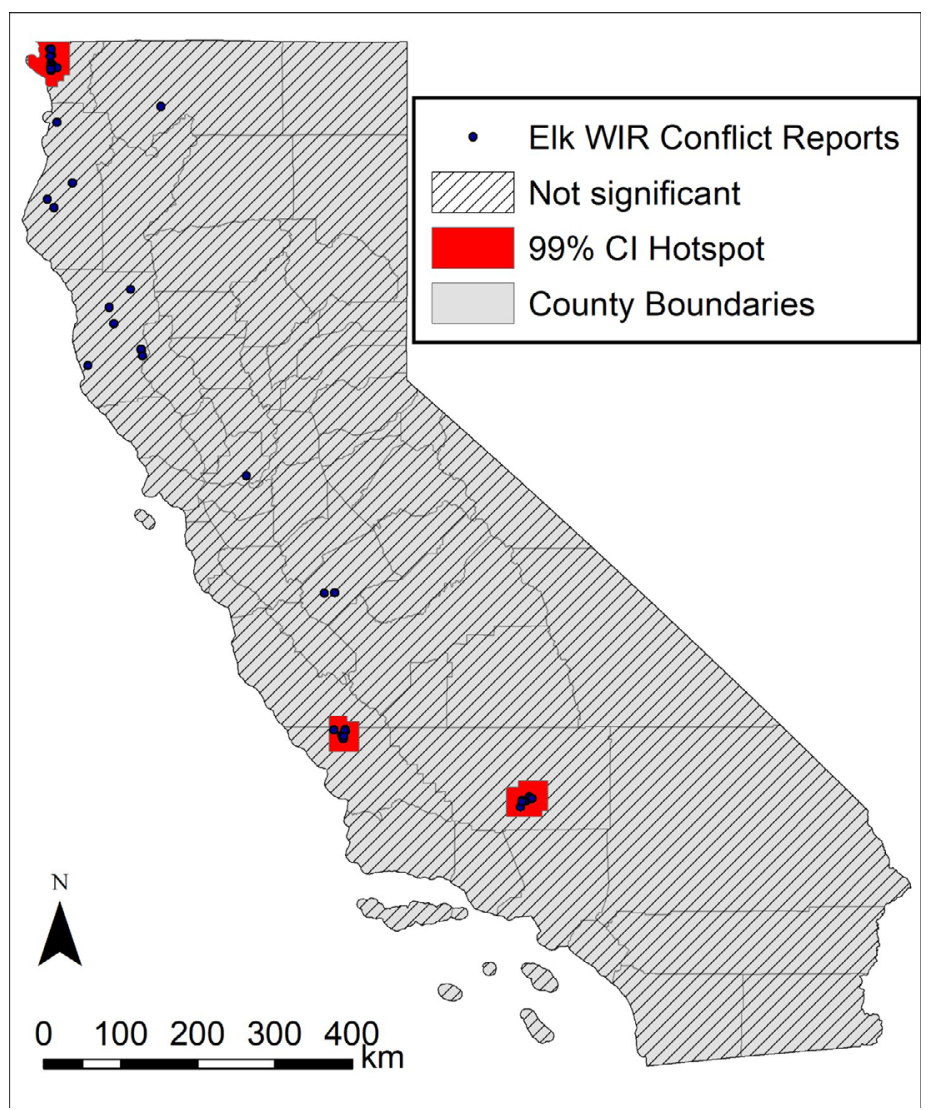

Figure 5. Hotspots of human-elk conflict in California from 4 Nov 2009-4 Oct 2020, shown as 99\% confidence intervals (CIs) of hotspots (red), identified using Optimized Hot Spot Analysis in ArcMap 10.4. All areas outside of $99 \%$ CIs were not significant in the Optimized Hot Spot Analysis. 
two of four lethal depredation permits that were issued, incident reports did not include follow up regarding whether planned actions were implemented (principle 3 ) or the results of implementing actions (principle 4).

\section{DISCUSSION}

Human-wildlife conflicts are on the rise where urban-wildland interfaces exist (e.g., Schell et al. 2020) and human-elk conflicts in California are no exception. Human-elk conflicts have increased in recent years (Fig. 2) concurrent with increases in distributions, numbers, and densities of elk throughout California (CDFW 2018). Using reports of humanelk conflict in CDFW's Wildlife Incident Reporting system, we identified four predominant themes of human-elk conflict in California, including property damage, conflicts with domestic animals, and habituation to humans. We also mapped three hotspots of human-elk conflict in California. Our analyses also suggested that principles of adaptive management were weakly or incompletely applied in CDFW responses to human-elk conflicts.

Property damage was the predominant type of human-elk conflict in California as reported in the WIR system and fence damage caused by elk was a major subtheme documented almost universally throughout reports from across the state. Fence damage often was attributed to elk not clearing top wires of fences while trying to jump over them. As such, damage to fences caused by elk passage may be alleviated by modifying fencing to facilitate crossing (Hanophy 2009) where total exclusion of elk is not necessary or practical. Where total exclusion of elk is desired (e.g., because of conflicts related to forage competition or crop depredation), game-proof fences, including woven-wire and electric fences (e.g., CDFW 2018), may be the most effective option; however, such fences may not be economically feasible. Future research is needed to better understand what type of exclosures are feasible for most property owners.

Fencing and exclosures cannot alleviate all health and safety concerns related to disease outbreaks. For example, recent outbreaks of Escherichia coli in leafy greens have occasionally been linked to contamination from cattle in pastures upslope from greens fields (USFDA 2020), but we do not know of any outbreaks that have been attributed to elk in California (however, elk can transmit E. coli pathogens; Franklin et al. 2013). Where consumption of crops by elk is the primary conflict, new deterrence methods, including use of tannins or polyrope electric fences may help alleviate conflicts with elk while maintaining safe and marketable commercial produce (Johnson et al. 2014, Monteith et al. 2019). Tannins, however, would not be useful to alleviate competition with cattle for forage, as cattle, like elk, are ruminants, and tannins impede digestion in ruminants (Robbins et al. $1987 \mathrm{a}, \mathrm{b})$. Future research also can help determine how aware landowners are of alternatives to exclusion fencing, and how awareness and implementations of such methods can be increased. Fencing also may be contraindicated when maintaining landscape connectivity is a management or conservation goal (Woodroffe et al. 2014). The California Department of Fish and Wildlife should continue to work with landowners and encourage implementation of fence-modifications that may alleviate conflict where total exclusion is not needed. In some situations, fence modifications could be trialed as part of an adaptive management response, particularly where private landowners, non-governmental organizations, CDFW, and other partners (e.g., Tribes, federal agencies) can work together to implement fence modifications and monitor their efficacy in alleviating human-elk conflict. 
Based on conflicts reported in the WIR system, we identified three hotspots of conflict in California, centered in Del Norte, San Luis Obispo, and Kern counties. The three hotspots of elk hotspots aligned with perceptions of where there are high levels of human-elk conflict in California (as indicated by anecdotal reports from regional CDFW staff; A. Gwinn, D. Hacker, C. Hilson, personal communications; and comments during public meetings). Several other areas we expected to be hotspots of conflict were not significant in the hotspot analysis. For example, anecdotally, human-elk conflicts are on the rise in Mendocino County (Moran et al. 2020), including several conflicts reported in the WIR system (Figs. 3, 4), yet Mendocino County was not identified as a conflict hotspot (Fig. 5). Similarly, human-elk conflicts have been reported anecdotally in Monterey and Inyo counties (J. Cann and M. Morrison, California Department of Fish and Wildlife, personal communications; CDFW 2018), but there were no reports of elk conflict in the WIR system for Monterey or Inyo counties. The relatively fewer hotspots than anticipated likely reflects a lack of reporting in the WIR system, rather than a lack of elk conflict in places like Mendocino and Inyo counties.

Public outreach, education, and communication could help spread awareness of the WIR system as a tool and resource in managing human-elk conflict. If more landowners are aware of the WIR system and how to communicate with CDFW about human-elk conflict, the WIR system will become a more reliable and valuable research tool for mapping conflict. Additional information on conflicts could help refine hotspot analyses, which ultimately could support regulatory changes aimed at alleviating human-elk conflicts. In identified conflict hotspots, as well as potential conflict hotspots (e.g., Inyo, Mendocino, Monterey counties), comprehensive population and conflict monitoring is essential for alleviating conflict, which is a primary goal of the California Elk Plan (CDFW 2018). In conflict hotspots, human dimensions research also may help with conflict mitigation or transformation, particularly relative to defining tolerable levels of conflict that can facilitate coexistence between humans and elk (Mekonen 2020).

Some RPs requested compensation for losses associated with fence damage, forage or crop depredation, or crop abandonment (due to potential health safety concerns). While some states (e.g., Colorado, Idaho, Montana) have programs to compensate landowners for depredation by wildlife, California has no such program. Compensation programs have documented mixed success (Wagner et al. 1997) and can have unintended consequences, including exacerbation of conflict (Bulte and Rondeau 2005). An alternative to compensation, and in some cases fencing, available to some landowners is enrollment in the CDFW Shared Habitat Alliance for Recreational Enhancement (SHARE) program. The SHARE program generates revenues through applications for hunting tags, which are issued for specific properties, thereby allowing hunting to reduce or disperse elk from conflict areas, while also incentivizing tolerance for elk on private lands (C. Hilson and V. Barr, California Department of Fish and Wildlife, personal communication). Anecdotally the SHARE program has been considered at least moderately successful in at least one conflict hotspot (i.e., Del Norte County) and hunting as a management tool for ungulate conflicts has been successful elsewhere (e.g., Shaw 1995; Walter et al. 2010). More work is needed to systematically evaluate the success of the SHARE program in alleviating human-elk conflict and promoting elk tolerance and coexistence between elk and humans.

Several types of human-elk interactions that we expected to see reported in the WIR system were notably absent, despite being potentially important sources of human-elk conflict, including elk-vehicle strikes and several zoonotic disease occurrences. This lack 
of reports on zoonotic disease and elk-vehicle strikes is likely due to the limits of the WIR system as a reporting tool rather than absence of those types of conflicts. For example, elk-vehicle strikes are generally reported to the California Roadkill Observation System administered by the Road Ecology Center at the University of California Davis (Waetjen and Shilling 2017). Wildlife health and disease concerns may be directly reported to CDFW staff in regional offices or the Wildlife Investigations Laboratory. Treponeme-associated hoof disease (TAHD) was first documented in Roosevelt elk in Del Norte County in April 2020 (Munk et al. 2020), and there is concern over whether it is transmissible between livestock and elk; yet there are no reports of elk with signs of TAHD in the WIR system. Similarly, there were no reports for concerns over Johne's disease, which is transmissible between cattle and elk, and is a source of conflict at Point Reyes National Seashore in northern California (Manning et al. 2003).

All WIR reports met at least one principle of adaptive management-conceptualizing the problem (Stankey et al. 2005; Williams et al. 2009; Williams 2011). Conceptualizing the problem is built into the framework of the WIR system as RPs must select a category for their report and then may write a longer description of the incident, which allows for further qualitative analysis. Many incidents described in the WIR reported CDFW staff advising RPs about potential actions to alleviate conflict (principle 2 of adaptive management). Some RPs described their implementation of actions (principle 3), as well as perceived outcomes of those actions (principle 4), and requested strategies be adapted based on their perceptions (principle 5). Generally, RPs reported hazing efforts that failed to keep elk away for extended periods of time, perceiving hazing efforts as a failure and using those observations to support requests for lethal depredation permits. Hazing may need to be ongoing to be successful (Walter et al. 2010); cessation of hazing undoubtedly can result in animals returning to an area, particularly if desirable resources are available.

The WIR system is focused on alerting CDFW to conflict and serving as a format for the RP to communicate concerns to CDFW. In this sense, it is largely a reactive tool and has limited utility to proactive or preventive management of conflict. Nevertheless, adaptive outcomes were proposed by CDFW in response to $n=32$ incidents of human-elk conflict in the WIR system. For example, changes to hunt-zone boundaries in San Luis and Kern counties represented an adaptive response to human-elk conflicts and were suggested because other methods for conflict alleviation had apparently failed (K. Denryter, personal observation). Similarly, in response to increasing elk conflicts in the North Coast EMU (which includes the third conflict hotspot of Del Norte County), hunting tag numbers were increased to help alleviate human-elk conflicts by reducing elk numbers, dispersing elk, and by enrolling landowners in the SHARE program (K. Denryter, personal observation).

To increase transparency and adherence to an adaptive management model for humanelk conflicts, we recommend several enhancements to CDFW responses to human-elk conflicts and the WIR system. First, we recommend CDFW staff responding to human-elk conflict work more closely with reporting parties to outline a plan of action and monitoring. Specific actions intended to alleviate human-elk conflicts should be identified and implemented and responses should be systematically measured through monitoring (principles 2 and 3 of adaptive management). The action and monitoring plan should identify what responses will be measured and at what scale - information necessary to evaluate the efficacy of actions (principle 4 of adaptive management). For example, if hazing is recommended, the type, frequency, intensity (e.g., number of humans involved in hazing, human-hours of 
effort), and duration of hazing activities should be specified. Information on responses of elk to hazing, such as distance moved, amount of time between elk leaving and returning to the property following hazing, group size (before and after hazing), etc. also should be collected and analyzed to evaluate the efficacy of various actions in response to human-elk conflicts, which would inform subsequent responses (principles 4 and 5 of adaptive management).

We recommend universal use of the WIR system by CDFW staff for human-elk conflicts (including CDFW staff cataloging incident reports received through means other than the WIR system). Changes to the WIR system that could help facilitate monitoring and adaptive management include the addition of fields to: describe the action and monitoring plan, enter monitoring data, evaluate efficacy of the response, and changes to the response as appropriate. Additionally, more thorough quantification of economic losses due to humanelk conflicts could be informative in developing loss-tolerance levels as part of an adaptive management model. Universal use of the WIR by CDFW staff may facilitate more comprehensive monitoring and rapid responses to conflicts that contribute to effective management needed to facilitate coexistence of humans and elk (Mekonen 2020).

\section{ACKNOWLEDGMENTS}

K. D. was supported by California Department of Fish and Wildlife Big Game Management Account funds. A. H. was supported by California Department of Fish and Wildlife Human Dimensions of Wildlife Conservation Federal Aid in Wildlife Restoration (PittmanRobertson) Grant. We are grateful to V. Monroe for inviting us to contribute this work and for her continued support throughout the manuscript preparation and publication process. We also are grateful to all RPs and CDFW staff who have reported and responded to conflict and documented incidents in the WIR - this work would not have been possible without their efforts. Three anonymous reviewers provided feedback that strengthened our manuscript.

\section{LITERATURE CITED}

Bautista, C., J. Naves, E. Revilla, N. Fernández, J. Albrecht, A. K. Scharf, R. Rigg, A. A. Karamanlidis, K. Jerina, D. Huber, S. Palazón, R. Kont, P. Ciucci, C. Groff, A. Dutsov, J. Seijas, P. I. Quenette, A. Olszańska, M. Shkvyria, M. Adamec, J. Ozolins, M. Jonozovič, and N. Selva. 2017. Patterns and correlates of claims for brown bear damage on a continental scale. Journal of Applied Ecology 54:282292.

Braun, V., and V. Clarke. 2006. Using thematic analysis in psychology. Qualitative Research in Psychology 3:77-101.

Bruskotter, J. T., J. J. Vaske, and R. H. Schmidt. 2009. Social and cognitive correlates of Utah residents' acceptance of thelethal control of wolves. Human Dimensions of Wildlife 14:119-132.

Bruskotter, J. T., and R. S. Wilson. 2014. Determining where the wild things will be: using psychological theory to find tolerance for large carnivores. Conservation Letters 7:158-165.

Bulte, E. H., and D. Rondeau. 2005. Why compensating wildlife damages may be bad for conservation. Journal of Wildlife Management 69:14-19.

California Department of Fish and Wildlife (CDFW). 2015. California state wildlife action plan. Volume I. Sacramento, California, USA. 
California Department of Fish and Wildlife (CDFW). 2018. Elk conservation and management plan. Sacramento, California, USA.

Drake, D., J. B. Paulin, P. D. Curtis, D. J. Decker, and G. J. San Julian. 2005. Assessment of negative economic impacts from deer in the northeastern United States. Journal of Extension 43:1RIB5.

Franklin, A. B., K. C. VerCauteren, H. Maguire, M. K. Cichon, J. W. Fischer, M. J. Lavelle, A. Powell, J. J. Root, and E. Scallan. 2013. Wild ungulates as disseminators of Shiga toxin-producing Escherichia coli in urban areas. PLoS ONE 8:8-13.

Gagnon, J. W., T. C. Theimer, N. L. Dodd, S. Boe, and R. E. Schweinsburg. 2007. Traffic volume alters elk distribution and highway crossings in Arizona. Journal of Wildlife Management 71:2318-2323.

Hanophy, W. 2009. Fencing with wildlife in mind. Colorado Division of Widlife, Denver, $\mathrm{CO}, \mathrm{USA}$.

Hegel, T. M., C. C. Gates, and D. Eslinger. 2009. The geography of conflict between elk and agricultural values in the Cypress Hills, Canada. Journal of Environmental Management 90:222-235.

Inskip, C., and A. Zimmermann. 2009. Human-felid conflict: A review of patterns and priorities worldwide. Oryx 43:18-34.

Johnson, H. E., J. W. Fischer, M. Hammond, P. D. Dorsey, W. D. Walter, C. Anderson, and K. C. Vercauteren. 2014. Evaluation of techniques to reduce deer and elk damage to agricultural crops. Wildlife Society Bulletin 38:358-365.

Lee, M. E., and R. Miller. 2003. Managing elk in the wildland-urban interface: Attitudes of Flagstaff, Arizona residents. Wildlife Society Bulletin 31:185-191.

Mackenzie, C. A., and P. Ahabyona. 2012. Elephants in the garden: financial and social costs of crop raiding. Ecological Economics 75:72-82.

Madden, F., and B. McQuinn. 2014. Conservation's blind spot: the case for conflict transformation in wildlife conservation. Biological Conservation 178:97-106.

Madhusudan, M. D. 2003. Living amidst large wildlife: livestock and crop depredation by large mammals in the interior villages of Bhadra Tiger Reserve, south India. Environmental Management 31:466-475.

Madison, J. S. 2008. Yosemite National Park: the continuous evolution of human-black bear conflict management. Human-Wildlife Interactions 54:160-167.

Manning, E. J. B., T. E. Kucera, N. B. Gates, L. M. Woods, and M. Fallon-McKnight. 2003. Testing for Mycobacterium avium subsp. paratuberculosis infection in asymptomatic free-ranging tule elk from an infected herd. Journal of Wildlife Diseases 39:323-328.

Mateo-Tomás, P., P. P. Olea, I. S. Sánchez-Barbudo, and R. Mateo. 2012. Alleviating human-wildlife conflicts: identifying the causes and mapping the risk of illegal poisoning of wild fauna. Journal of Applied Ecology 49:376-385.

Mekonen, S. 2020. Coexistence between human and wildlife: the nature, causes and mitigations of human wildlife conflict around Bale Mountains National Park, Southeast Ethiopia. BMC Ecology 20:1-9. BioMed Central.

Michalak, K., C. Austin, S. Diesel, J. M. Bacon, P. Zimmerman, and J. N. Maslow. 1998. Mycobacterium tuberculosis infection as a zoonotic disease: transmission between humans and elephants. Emerging Infectious Diseases 4:283-287.

Monteith, K. B., K. L. Monteith, and J. A. Jenks. 2019. Condensed tannins as a deterrent 
to crop depredation by white-tailed deer: effects of concentration and learning. Wildlife Society Bulletin 43:693-700.

Moran, A., K. Morefield, and K. Denryter. 2020. Report on spring aerial surveys of tule elk (Cervus canadensis nannodes) in the Mendocino Elk Management Unit. California Department of Fish and Wildlife, Eureka, CA, USA. 10.13140/ RG.2.2.11670.98888

Munk, B. A., E. L. Lantz, and K. Denryter. 2020. Strategic surveillance plan for treponeme associated hoof disease in California. California Department of Fish and Widlife, Sacarmento, CA, USA. 10.13140/RG.2.2.30391.65441

Redpath, S. M., B. E. Arroyo, F. M. Leckie, P. Bacon, N. Bayfield, R. J. Guttiérrez, and S. J. Thirgood. 2004. Using decision modeling with stakeholders to reduce humanwildlife conflict: a raptor-grouse case study. Conservation Biology 18:1-10.

Rhyan, J. C., P. Nol, C. Quance, A. Gertonson, J. Belfrage, L. Harris, K. Straka, and S. Robbe-Austerman. 2013. Transmission of brucellosis from elk to cattle and bison, Greater Yellowstone Area, USA, 2002-2012. Emerging Infectious Diseases 19:1992-1995.

Robbins, C. T., T. A. Hanley, A. E. Hagerman, O. Hjeljord, D. L. Baker, C. C. Schwartz, and W. W. Mautz. 1987a. Role of tannins in defending plants against ruminants: reduction in protein availability. Ecology 68:98-107.

Robbins, C. T., S. Mole, A. E. Hagerman, and T. A. Hanley. 1987b. Role of tannins in defending plants against ruminants: reduction in dry matter digestion. Ecology 68:1606-1615.

Schell, C. J., L. A. Stanton, J. K. Young, L. M. Angeloni, J. E. Lambert, S. W. Breck, and M. H. Murray. 2020. The evolutionary consequences of human-wildlife conflict in cities. Evolutionary Applications 1-20.

Shaw, M. G. 1995. An evaluation of Oklahoma's depredation program for handling deer damage to agricultural crops. Great Plains Wildlife Damage Control Workshop Proceedings 449:60-62.

Slagle, K., R. Zajac, J. Bruskotter, R. Wilson, and S. Prange. 2013. Building tolerance for bears: a communications experiment. Journal of Wildlife Management 77:863869.

Stankey, G. H., R. N. Clark, and B. T. Bormann. 2005. Adaptive management of natural resources: theory, concepts, and management institutions. USDA Forest Service General Technical Report PNW 1-73.

Van Tassell, L. W., B. Yang, and C. Phillips. 2000. Depredation Claim Behavior of Wildlife in Wyoming. Journal of Agricultural and Applied Economics 32:175-188.

Treves, A., L. Naughton-Treves, E. K. Harper, D. J. Mladenoff, R. A. Rose, T. A. Sickley, and A. P. Wydeven. 2004. Predicting human-carnivore conflict: a spatial model derived from 25 years of data on wolf predation on livestock. Conservation Biology 18:114-125.

United States Food and Drug Administration (USFDA). 2020. Factors potentially contributing to the contamination of romaine lettuce implicated in the three outbreaks of E. coli $\mathrm{O} 157: \mathrm{H} 7$ during the fall of 2019. Silver Spring, MD, USA. Available from: $<$ https://www.fda.gov/food/outbreaks-foodborne-illness/factors-potentially-contributing-contamination-romaine-lettuce-implicated-three-outbreaks-e-coli>

VerCauteren, K. C., M. J. Lavelle, and S. Hygnstrom. 2006. Fences and deer-damage man- 
agement: a review of designs and efficacy. Wildlife Society Bulletin 34:191-200. Waetjen, D. P., and F. M. Shilling. 2017. Large extent volunteer roadkill and wildlife observation systems as sources of reliable data. Frontiers in Ecology and Evolution $5: 1-10$.

Wagner, K. K., R. H. Schmidt, and M. R. Conover. 1997. Compensation programs for wildlife damage in North America. Wildlife Society Bulletin 25:312-319.

Walter, W. D., M. J. Lavelle, J. W. Fischer, T. L. Johnson, S. E. Hygnstrom, and K. C. VerCauteren. 2010. Management of damage by elk (Cervus elaphus) in North America: a review. Wildlife Research 37:630-646.

Williams, B. K. 2011. Adaptive management of natural resources-framework and issues. Journal of Environmental Management 92:1346-1353.

Williams, B. K., R. C. Szaro, and C. D. Shapiro. 2009. Adaptive management: the U.S. Department of the Interior technical guide. Adaptive Management Working Group, U.S. Department of the Interior, Washington, D.C., USA.

Woodroffe, R., S. Hedges, and S. M. Durant. 2014. To fence or not to fence. Science 344:46-48.

Submitted 14 December 2020

Accepted 22 January 2021

Associate Editor was V. Monroe 